пресингу у примагістральних та селітебних біотопах, що свідчить про значну лабільність виду у змінних умовах середовища та про його вику біоіндикаційну цінність. Максимально інформативними біоіндикаційними параметрами $є$ площа листкової пластинки, загальна довжина рослини та середня кількість квітконосів і їх діаметр у перерахунку на одну особину популяції.

\title{
Література:
}

1. Коваленко I.M. Структура популяцій домінантів трав'яночагарничкового ярусу в лісових фітоценозах Деснянсько-Старогутського національного природного парку. Онтогенетична структура. Український ботанічний журнал. 2005. Т. 62, № 5. С. 707-714.

2. Вихор Б.І. Проць Б.Г. Борщівник Сосновського (Heracleum sosnowskyi Manden.) на Закарпатті: екологія, поширення та вплив на довкілля. Біологічні студії, 2012. С. 185-196.

3. Протопопова В.В. Небезпечні бур'яни. Біологічні забруднювачі довкілля м. Києва / В.В. Протопопова. М.В. Шевера. Київ : ТОВ «Поліграф-Експрес», 2010. 48 с.

4. Різничук Н.I. Онтогенез Polygonatum multiflorum L. на Прилуквинській височині. Біологічний вісник: матеріали XVI міжнародної наукової конференції «Роль ботанических садов в изучении онтогенеза интродуцированных растений». 2008. Т. 12, № 2. С. 54-56.

DOI https://doi.org/10.30525/978-9934-26-006-3-21

\section{СЕЗОННИЙ РОЗВИТОК САДОВИХ ТРОЯНД ЗА КЛІМАТИЧНИХ ЗМІН В УМОВАХ СТЕПУ УКРАЇНИ}

\author{
Чипиляк Т. Ф. \\ кандидат біологічних наук,
} завідувачка відділу природної та культурної флори

Криворізький ботанічний сад Національної академії наук України м. Кривий Ріг, Дніпропетровська область, Украӥна

Зміна клімату відноситься до екологічних ризиків, які визначають екологічну безпеку навколишнього середовища і проявляються у зміні температури, атмосферних опадів, гідрологічного режиму та відхилення їх параметрів від кліматичної норми певної географічної 
широти [5, с. 133]. Індикаторами змін температури, гідрологічних режимів, сонячної радіації є рослини, адже динаміка настання фенофаз, терміни початку і тривалості фенологічних циклів знаходяться під постійним впливом сезонних змін (зима-літо, день-ніч) [2]. В свою чергу, здатність рослин, як природної, так і культурної флори, уникати екологічного стресу за рахунок зміни ритмів росту та розвитку розглядається як важливий механізм стійкості до несприятливих або нових чинників середовища [1].

Троянди завдяки своїм декоративним властивостям - пишному цвітінню, яскравому забарвленню і гарній формі квітки, займають одне 3 провідних місць у декоративному садівництві. Їх використання забезпечує тривалий декоративний ефект у різних видах квітників, тому важко знайти садову культуру, яка більш часто вживається в оформленні населених пунктів України. Мета досліджень - визначення особливостей сезонного розвитку садових троянд в умовах Криворізького ботанічного саду НАН України протягом $1997-2018$ років для оптимізації асортименту квітникових рослин у міських насадженнях степової зони України.

Місто Кривий Ріг, на території якого проводилися дослідження, знаходиться на південному заході Дніпропетровської області у степовій зоні і його протяжність 3 півночі на південь становить понад 100 км. Згідно 3 агрокліматичним районуванням території України, Криворіжжя входить до складу посушливої, дуже теплої агрокліматичної зони. За останні 60 років посушливими $є$ кожні 3-4 роки на одне десятиліття, а сильні посухи бувають 1 раз на 5-10 років, коли за вегетаційний період випадає усього 100-150 мм опадів [3, 7]. Згідно спостережень метеостанції, розташованої на території Кривого Рогу, за останні 30 років середньорічна температура повітря піднялася на $2^{0} \mathrm{C}$ [8]. Спостереження за колекційними рослинами проводилося за методикою фенологічних спостережень у ботанічних садах, запропонованою Радою ботанічних садів СРСР [6]. Опрацьовано матеріал щодо початку та тривалості основних фенофаз за останні 22 роки: початок відростання, початок квітування, початок масового квітування, тривалість цвітіння та вегетації. Для зручності сприйняття матеріалу результати виділені по п'ятирічкам і подані за середніми показниками. Дослідженнями охоплено колекційні зразки, які розподілені за основними садовими групами: Hybrid Tea, Floribunda, Miniature та Rambler. 3 кожної групи виділено сорти за якісними (мали яскраво виражені якості даної групи) та кількісними (кущі кожного з сортів одного віку, добре розвинені та стійкі до 
захворювань) параметрами, які досить повно відображають структуру колекції троянд. Досліджувані сорти також відрізняються за типом фенологічного розвитку [4]. Так, Rambler відносяться до консервативного типу фенологічного розвитку (характерний інтенсивний, одноразовий ріст пагонів, які визрівають до кінця вегетаційного сезону та коротке квітування) i характеризуються найвищою зимостійкістю. Сорти Hybrid Tea та Miniature групи - до динамічного типу, якому характерна значна залежність сезонного ритму розвитку від зовнішніх умов. При сприятливих погоднокліматичних умовах інтродуценти характеризуються тривалим ростом пагонів та повторним квітуванням i відзначаються середніми показниками зимостійкості. До перехідного феноритмотипу можна віднести сорти троянд Floribunda. Їм властива здатність до безперервного росту пагонів, часто вони квітують тільки один раз на початку сезону та мають середні і низькі показники зимостійкості.

Аналіз отриманих результатів свідчить, що у 1997-2001 роках першими, в кінці березня - початку квітня, починали вегетацію сорти групи Rambler i тільки наприкінці квітня - сорти групи Hybrid Tea (найпізніші терміни). Останнє десятиліття (2009-2018рр.) вегетація троянд, в незалежності від садової групи, розпочиналася переважно впродовж II-III декади березня. Зауважимо, що протягом останніх десяти років у троянд Hybrid Tea та Floribunda відростання починалося на 11-14 діб раніше, ніж 20 років тому, то у сортів Rambler - на 4-6 діб. Відповідно, за останні 22 роки збільшилися терміни вегетації троянд в кліматичних умовах Степової зони України: у Hybrid Tea - на 36 діб, Miniature - на 24 доби, Floribunda - на 14 діб, Rambler - на 12 діб.

Особливу увагу було приділено аналізу термінів початку та масовому квітуванню троянд які найбільш характерно відображають відмінності розвитку садових груп. Так, у 1997-2001 рр. троянди починали цвітіння наприкінці травня (Rambler) - I декаді червня (Miniature). Найпізніше, в другій половині червня, розквітали троянди Floribunda та Hybrid Tea. Наступне п'ятиріччя (2002-2007 pp.) відзначається зміною термінів на більш ранні - II декада травня (Rambler) і початок червня (Miniature, Floribunda та Hybrid Tea). Відповідна тенденція відзначена i в подальшому - квітування починалося на 5-7 діб раніше кожні п'ять років. Останні роки троянди всіх садових груп квітувати розпочинають майже одночасно (з різницею в 2-3 дні) в другій половині травня, тобто на 10-12 діб раніше ніж 22 років тому. 
Масового характеру квітування троянд у 1997-2001 pр. набувало в II-III декаді червня. Зазвичай, на 5-7 діб виткі троянди випереджали інші сорти. Натомість, у 2014-2018 роках масово розцвітати троянди починали вже на початку червня - у окремих сортів різниця за 22 років досягала 25-28 діб (група Hybrid Tea - 'Baccara', 'Garden Party', 'Opera'). Тоді як, у сортів Rambler ця різниця складає тільки 10-15 діб ('Heidelberg', ('Grand Hotel', 'New Dawn', 'Robusta', 'Veilchenblay').

Дослідження тривалості квітування показало, що за останні 22 роки поступове його збільшення було властиве трояндам групи Hybrid Tea (у 1,3-1,9 рази) та що ремонтантним сортам групи Rambler (у 1,2 рази). У троянд групи Floribunda тривалість цвітіння або не змінилася, або зменшилася на 45-48\% ('Centenaire de Lourdes', 'Else Poulsen'). Слід відзначити, що мініатюрні сорти виявили найбільш різноманітні особливості ритміки цвітіння - сорти 'Hi-Ho', 'Little Buckaroo', 'Pink Cameo' та 'Red Cascade' збільшили його тривалість; 'Green Ace', 'Perla de Alcanada' та 'Polka Dot' скоротили цвітіння; сорт 'Ні-Но' виявив ремонтантність, що не відповідає його сортовим характеристикам.

Отже, вивчення особливостей сезонного розвитку садових троянд в умовах Степової зони України та аналіз отриманих результатів дає можливість зробити наступні висновки. Доведено, що рослини реагують на зміни температурного режиму повітря, а тривалість основних фаз сезонного розвитку пов'язана з кліматичними умовами та залежить від сортових особливостей троянд. Загальним для всіх груп троянд визначено більш ранній початок вегетації (на 6-14 діб) та збільшення вегетаційного періоду (на 12-36 діб). Цвітіння троянд також починається раніше - на 10-12 діб, а масове квітування - на 15-20 діб, ніж 22 роки тому. Більшою варіабельністю відзначалися терміни початку і тривалості фаз вегетативного, ніж генеративного розвитку. Для сортів Rambler, які відносяться до консервативного типу розвитку, характерні найменші показники часових змін. У переважної більшості досліджених сортів групи Floribunda період квітування або не змінився, або зменшився на 45-48\%. Найбільш значні відмінності у ритмах розвитку в останні роки, в порівнянні з 1997 роком, були характерні для Hybrid Tea, які відносяться до динамічного типу фенологічного розвитку - масове цвітіння відбувається на 20-28 діб раніше та зафіксовано збільшення у 1,3-1,9 рази тривалості квітування. Найбільш різноманітні особливості ритміки даної фази виявили мініатюрні сорти, для яких було характерно як ії збільшення, так i зменшення. Припускаємо, що такі значні відмінності вказують на вищу 
пластичність чайно-гібридних та мініатюрних троянд на відміну від витких сортів, які виявляють меншу адаптаційну здатність.

\section{Література:}

1. Булах П.Е. Фенологические критерии устойчивости в интродукции растений / Інтродукція рослин. 2005. № 4. С. 9-19.

2. Сремеєв В.М. Регіональні аспекти глобальної зміни клімату / Вісник НАН України. 2003. № 2. С. 24-28.

3. Казаков В.Л., Сметана М.Г., Шипунова В.О. Паранько І.С. та ін. Природнича географія Кривбасу. Кривий Ріг: КДПУ. 2005. 156 с.

4. Козловский Б.Л., Козловский Б.Л., Федоринова О.И., Куропятников М.В. Закономерности фенологии древесных растений при интродукции в ботаническом саду ЮФУ / Международные чтения, посвященные 110-летию со дня рождения дбн, профессора Леонида Ивановича Рубцова: материалы конф. (м. Київ, 15-18 мая 2012 р.). Київ: Моляр С.В. 2012. С. 295-299.

5. Приходько М.М. Екологічна безпека природних і антропогенно модифікованих геосистем: монографія. Київ: Центр екологічної освіти та інформації. 2013. $201 \mathrm{c.}$

6. Рекомендации Совета ботсадов СССР. Киев. 1990. 184 с.

7. Шипунова В.О., Маханько І.В. Прояв глобального потепління на території Криворіжжя / Географічні дослідження Кривбасу. Фізична географія, економічна і соціальна географія, геоекологія, історична географія, викладання географії : матеріали кафедральних науководослідних тем. Вип. 1. 2006. С. 7-11.

8. Електронний ресурс - Сайт погоди. http://rp5.ua 